\title{
Transduction of Auxotrophic Markers in a Chloramphenicol- producing Strain of Streptomyces
}

\author{
By COLIN STUTTARD \\ Microbiology Department, Dalhousie University, Halifax, Nova Scotia, Canada
}

(Received 29 August 1978)

\section{INTRODUCTION}

Phage-mediated transduction (Zinder \& Lederberg, 1952) has been used extensively for genetic analysis in several bacteria (Levinthal, 1974) and has been particularly useful for the analysis of small regions of bacterial genomes (Hartman et al., 1960). In Streptomyces, coarse genetic mapping is reasonably well advanced, but little fine structure genetic mapping has been attempted, principally because systems such as transduction are presently unavailable (Bibb et al., 1978). The only previous report of transduction in an actinomycete was by Alikhanian et al. (1960). Unfortunately, the strain used, Actinomyces (Streptomyces) olivaceus, had few genetic markers and no subsequent data was published. Therefore, the significance of that report remains uncertain (Hopwood et al., 1973).

The present work was undertaken to find phages capable of transduction in Streptomyces and thereby provide a further means of genetic analysis and manipulation in these biologically, commercially and medically important micro-organisms.

This paper reports phage-mediated transduction in the chloramphenicol-producing streptomycete Streptomyces sp. 3022a strain 13s and its derivatives. A provisional linkage map of markers in some of the strains used was previously derived by conjugation-type crosses (Francis et al., 1975).

\section{METHODS}

Strains. Auxotrophs (pur-2, pur-5, pur-6, nic-1, trp-1) were derived from the c loramphenicol-producing prototrophic strain of Streptomyces sp. 3022a called 13s (Francis et al., 1975). Strain 13s1, a prototroph unable to produce chloramphenicol, was derived from strain $13 \mathrm{~s}$ and was previously designated A22NY (Michelson \& Vining, 1978). Mutant ade-2 was isolated from strain 13s1. All ade and pur mutants grew in the presence of adenine or guanine $\left(11 \mu \mathrm{g} \mathrm{ml}^{-1}\right)$. Streptomyces coelicolor $\mathrm{A} 3(2)$ and $S$. lividans 66 strains came from stocks at the John Innes Institute, Norwich; stocks of 25 other streptomycetes, including strains PD04828, ATCC 10595, ATCC 15068 and S13 of S. venezuelae, were generously provided by Dr L.C. Vining.

Isolation of phage. Dowding's (1973) procedure for isolating phage from soil was followed with minor modifications. Phage eluted from a plaque of $\phi \mathrm{SV} 1$ obtained on strain 13s1 was purified by two further successive single plaque isolations on 13s1. The final eluate was used to raise high-titre lysates in soft agar overlays. Phage was harvested by low-speed centrifugation $(1700 \mathrm{~g}, 15 \mathrm{~min})$ to remove overlay debris, followed by membrane filtration $(0.45 \mu \mathrm{m}$ pore size) and concentration by high-speed centrifugation $(50000 \mathrm{~g}, 90 \mathrm{~min})$. Phage particles in the resulting pellets were resuspended in sterile buffer by standing overnight at $4{ }^{\circ} \mathrm{C}$. A final low-speed centrifugation removed any remaining subcellular debris. Phage buffer used in the preparation, dilution and storage of lysates consisted of $4 \mathrm{~mm}-\mathrm{Ca}\left(\mathrm{NO}_{3}\right)_{2}, 10 \mathrm{~mm}-\mathrm{Tris} / \mathrm{HCl}$ $(\mathrm{pH} 7.5)$ and $5 \times 10^{-3} \%(\mathrm{w} / \mathrm{v})$ gelatin. Other phage techniques were generally those described by Dowding (1973). A host strain designation in parentheses after the phage symbol indicates the last host for that particular lysate.

Culture media and methods. A routine complex medium (GYM), consisting of $0.5 \%(\mathrm{w} / \mathrm{v})$ glucose, $0.4 \%$ $(\mathrm{w} / \mathrm{v})$ yeast extract (Difco), $1.0 \%$ (w/v) malt extract (Difco) and $2.0 \%$ Difco Bacto-agar, was used for growth and sporulation of all strains. For phage propagation, $2.3 \%(\mathrm{w} / \mathrm{v})$ nutrient agar (Difco) supplemented with $4 \mathrm{~mm}-\mathrm{Ca}\left(\mathrm{NO}_{3}\right)_{2}$ and $0.5 \%(\mathrm{w} / \mathrm{v})$ glucose $(\mathrm{NCG})$ served as a routine basal medium. Minimal medium 
(MM), with supplements where necessary, and general techniques for handling streptomycetes were those described by Hopwood (1967), except that spores were harvested from plates rather than slants. Spore stocks were stored in $20 \%(\mathrm{w} / \mathrm{v})$ glycerol at about $-18{ }^{\circ} \mathrm{C}$.

Transduction procedures. Donor phage and recipient spores, generally in the ratio of about 20 plaqueforming units (p.f.u.) of phage to 1 colony-forming unit (c.f.u.) of bacteria (mostly, if not all, spores at $5 \times 10^{6}$ to $5 \times 10^{7}$ per plate), were spread together directly on to selective media which would support growth of recombinants but not the recipients. Plates spread with recipient alone or phage alone were used as controls. In half-plate tests (used in initial experiments and in all crosses with donor strain 13s1), duplicate plates were spread with about $10^{8}$ c.f.u. of recipient spores and allowed to dry. Approximately $5 \times 10^{9}$ p.f.u. of donor phage were then spread on one half of each prepared plate, the other half serving as an uninfected recipient control. Recovery of prototrophs was enhanced by supplementing MM with proline even though none of the recipients required this amino acid. Spore germination and slight growth of recipients on selective media was apparently necessary for prototrophic colonies to appear: the Trp ${ }^{-}$recipient strain $\operatorname{trp}-1$ (Francis et al., 1975) gave prototrophs only in the presence of low levels of tryptophan. Yields of prototrophs were also increased up to eightfold by pretreatment of donor phage with ultraviolet (u.v.) light (256 nm wavelength) to a survival of 0.1 to $0.4 \%$ (p.f.u.). Inoculated plates were incubated at $30{ }^{\circ} \mathrm{C}$ for $4 \mathrm{~d}$.

\section{RESULTS AND DISCUSSION \\ Isolation and some properties of $\phi \mathrm{SV} 1$}

$\phi \mathrm{SV} 1$ was one of several different phages isolated from soil obtained from Belize, Central America. It formed small, slightly turbid plaques on strain 13s1, and clearer plaques on some strains of $S$. venezuelae. Particles of $\phi \mathrm{SV} 1$ were similar in electron microscopic appearance to most other streptomyces phages, both virulent (Dowding, 1973) and temperate (Dowding $\&$ Hopwood, 1973). The host range of $\phi \mathrm{SV} 1$ was apparently limited to Streptomyces sp. 3022a strains and some strains of $S$. venezuelae.

\section{Host specificities}

Reproducible host-controlled differences in efficiencies of plating (e.o.p.) of phages (Table 1) suggested the existence of different DNA restriction-modification (R-M) specificities in these streptomycetes. Although R-M systems in Streptomyces are known (Chater, 1978) or inferred (Lomovskaya et al., 1977), the $S$. venezuelae system(s) may include the first examples of different host restriction specificities affecting the same phage in Streptomyces. Qualitative spot tests of $\phi \mathrm{SV} 1$ on patches of mycelia inoculated on to NCG plates revealed no sensitive strains among 23 different streptomycetes tested, including $S$. coelicolor A3(2), S. lividans 66 and S. venezuelae strains S13 (Jones \& Bradley, 1965) and ATCC 15068. The test was sufficiently sensitive to detect infection of the restricting host strain PD04828 by $\phi \mathrm{SV} 1(13 \mathrm{~s} 1)$ which gave relative e.o.p. values of $2 \times 10^{-4}$ to $5 \times 10^{-4}$ in overlay tests (Table 1).

Virulence of $\phi \mathrm{SV} 1$, as opposed to a possible temperate nature, was indicated by the recovery of phage-free, $\phi \mathrm{SV} 1$-sensitive clones from pseudolysogenic transductants and recipient parental colonies growing on GYM after phage infection. Patches of seriallyisolated single clones grown on GYM were replicated to NCG and then overlaid with softagar containing spores of strain $13 \mathrm{~s} 1$. They were deemed to be phage-free when no lysis was evident in the overlays after $2 \mathrm{~d}$ at $30^{\circ} \mathrm{C}$. True lysogens, carrying temperate prophage, would not be expected to segregate phage-sensitive clones under these conditions (Welsch, 1969).

\section{Transduction tests}

A summary of results obtained in full-plate transduction tests (except with donor strain $13 \mathrm{~s} 1$ ) is given in Table 2. The data are from single experiments with u.v.-irradiated phage and show that similar frequencies of prototrophs were obtained in all heterologous crosses $\left(5 \times 10^{-7}\right.$ to $16 \times 10^{-7}$ per input phage p.f.u. prior to u.v.-irradiation).

Two experiments showed that prototrophs resulted from phage infection of recipient 
Table 1. Effect of previous host on efficiency of plating* of $\phi \mathrm{SV} 1$

\begin{tabular}{|c|c|c|c|}
\hline \multirow[b]{2}{*}{ Previous host } & \multicolumn{3}{|c|}{ Indicator strain } \\
\hline & $13 \mathrm{~s} 1$ & PD04828 & ATCC 10595 \\
\hline $\begin{array}{l}\text { 13s1 } \\
\text { PD04828 } \\
\text { ATCC } 10595\end{array}$ & $\begin{array}{c}1 \\
1 \times 10^{-2}-3 \times 10^{-2} \\
3.5 \times 10^{-2}\end{array}$ & $\begin{array}{c}2 \times 10^{-4}-5 \times 10^{-4} \\
1 \\
9 \times 10^{-1}\end{array}$ & $\begin{array}{c}2 \times 10^{-2} \\
4 \times 10^{-1} \\
1\end{array}$ \\
\hline
\end{tabular}

Table 2. Transduction by $\phi \mathrm{SV} 1$ in Streptomyces sp. 3022a (13s)

\begin{tabular}{|c|c|c|c|c|c|}
\hline \multicolumn{3}{|c|}{ Recipient strain } & \multicolumn{3}{|c|}{ Donor strain } \\
\hline $\begin{array}{l}\text { Counterselective } \\
\text { marker }\end{array}$ & $\begin{array}{l}10^{-6} \times \text { c.f.u. } \\
\text { per plate* }\end{array}$ & $\begin{array}{l}\text { Revertants } \\
\text { per plate }\end{array}$ & ade-2 & $\begin{array}{c}p u r-6 \\
\text { Prototroph frequencies } \uparrow\end{array}$ & $13 \mathrm{~s} 1$ \\
\hline ade-2 & $7 \cdot 2$ & 0 & 0 & $5 \cdot 6(440)$ & $7 \cdot 4(640)$ \\
\hline pur-2 & 21 & 0 & $\geqslant 4.7$ & $6 \cdot 2(480)$ & $6.4(640)$ \\
\hline pur-5 & 29 & 24 & $\geqslant 4.7 \quad(1000)$ & $7 \cdot 2(590)$ & $6 \cdot 1(620)$ \\
\hline pur-6 & $7 \cdot 5$ & 2 & $3.25(700)$ & 0 & $5 \cdot 3(540)$ \\
\hline nic-I & 50 & 0 & ND & ND & $1.5(76)+$ \\
\hline $\operatorname{ser}-1$ & 28 & 35 & $10 \quad(1000)$ & $16 \quad(620)$ & $12(600)$ \\
\hline $\operatorname{trp}-1$ & 5 & 6 & $5 \cdot 1 \quad(550)$ & $5 \cdot 5(210)$ & $6 \cdot 5(330)$ \\
\hline
\end{tabular}

ND, Not done.

* Extrapolated from viable counts made on GYM with dilute spore suspensions.

$\uparrow$ Per $10^{2}$ donor phage (unirradiated p.f.u.); input phage (about $10^{9}$ p.f.u. per plate) was assayed prior to u.v.-irradiation to 0.1 to $0.4 \%$ survival; numbers in parentheses indicate approximate colony counts per plate after $4 \mathrm{~d}$ incubation, except for crosses with donor strain $13 \mathrm{~s} 1$ where numbers are totals for duplicate half-plate tests.

$\ddagger$ This cross was done on MM; media for all other crosses contained proline $\left(56 \mu \mathrm{g} \mathrm{ml}^{-1}\right)$.

bacteria. Firstly, when the concentration of unirradiated donor phage was increased (e.g. from $10^{8}$ to $10^{9}$ p.f.u. per plate with the recipient concentration unchanged at $10^{7}$ ade- 2 c.f.u. per plate), the number of prototrophs per plate increased (from 9 to 153). However, the relationship was not linear, probably because lysis-from-without would have been a factor at high phage concentrations ( $10^{10}$ p.f.u. gave 525 colonies per plate; Ely \& Johnson, 1977). Secondly, when rabbit anti- $\phi \mathrm{SV} 1$ serum (K value approximately 650 by the method of Eisenstark, 1976) was spread together with recipient spores before $\phi \mathrm{SV} 1(13 \mathrm{~s} 1)$ was added, the number of prototrophs arising was less than $3 \%$ of that obtained on plates spread with a similar concentration of serum obtained from the rabbit prior to its exposure to $\phi \mathrm{SV} 1$.

Evidence of prototrophs appearing after phage infection of auxotrophs would not, by itself, warrant the conclusion that transduction had occurred. The data might also be explained by phage-induced reversion (Alikhanian \& Iljina, 1960). However, the generalized nature of the effect makes such an explanation unlikely; a provisional linkage map for Streptomyces sp. 3022a (Francis et al., 1975) showed clearly separate locations for the markers pur-2, nic- 1 and $t r p-1$ which gave prototrophs in heterologous crosses (see Table 2). Perhaps the most significant evidence indicating transduction was the absence of colonies in homologous crosses involving strains ade-2 and pur- 6 while colonies were produced in heterologous crosses with these strains (Table 2). Samples of colonies appearing on transduction plates (usually 6 to 12 per cross) were tested and prototrophs were recovered from each cross. Most were phage-free (the remainder being pseudolysogenic) and all were sensitive to $\phi \mathrm{SV} 1$. Stability of transductants was not checked systematically although limited testing revealed no evidence of segregation of the ade-2 recipient marker. Also, no evidence of marker linkage (cotransduction) was found, although frequencies of less than $8 \%$ would not have been detected.

In common with some other transducing phages in Gram-positive organisms (Hemphill \& 
Whiteley, 1975; Ely \& Johnson, 1977), apparent virulence of $\phi$ SV1 did not prevent recovery of transductants. The explanation that inefficient adsorption of $\phi \mathrm{Cr} 30$ allowed the survival of transductants in Caulobacter (Ely \& Johnson, 1977) may also apply to $\phi$ SV1 (unpublished data). Slow or inefficient adsorption has been found with several streptomyces phages (Welsch, 1969; Dowding, 1973; Novikova et al., 1973).

While the taxonomic classification of Streptomyces sp. 3022a is presently unresolved, the host-range limitations of $\phi \mathrm{SV} 1$ support the view that, along with other chloramphenicolproducing streptomycetes, Streptomyces sp. $3022 \mathrm{a}$ is probably a strain of $S$. venezuelae. A very close relationship (presumably DNA homology) between $3022 \mathrm{a}$ (13s strains) and S. venezuelae strain PD04828 is also indicated by preliminary data showing that the latter can serve as a prototrophic donor in transductions with 13s strains (unpublished data).

In summary, the present data provide the first evidence for transduction by an apparently virulent phage in a genetically mapped streptomycete. Exploitation of this system may facilitate fine structure genetic mapping in strain $13 \mathrm{~s}$, including possible analysis of genes controlling chloramphenicol biosynthesis.

I thank Mary Dwyer for excellent technical assistance, and David Hopwood and Keith Chater for encouragement to undertake the search for transduction in Streptomyces. This work was supported by operating grant MA-6037 from M.R.C., Canada.

\section{REFERENCES}

Alikhanian, S. I., Iljina, T. S. \& Lomovskaya, N. D. (1960). Transduction in Actinomycetes. Nature, London 188, 245-246.

Alikhanian, S. I. \& Iljina, T. S. (1960). Mutagenic action of actinophage. Journal of Genetics 57, 11-18.

BiBB, M. J., WARD, J. M. \& Hopwood, D. A. (1978). Transformation of plasmid DNA into Streptomyces at high frequency. Nature, London 274, $398-400$.

Chater, K. F. (1978). Restriction in Streptomyces. Proceedings of the International Symposium on Nocardia and Streptomyces, Warsaw, October 1976, pp. 303-311.

Dowding, J. E. (1973). Characterization of a bacteriophage virulent for Streptomyces coelicolor A3(2). Journal of General Microbiology 76, 163176.

Dowding, J. E. \& Hopwood, D. A. (1973). Temperate bacteriophages for Streptomyces coelicolor A3(2) isolated from soil. Journal of General Microbiology 78, 349-359.

EISENSTARK, A. (1976). Bacteriophage techniques. In Methods in Virology 1, 449-524. Edited by K. I. Maramorosch and H. Koprowski. New York and London: Academic Press.

Ely, B. \& Johnson, R. C. (1977). Generalized transduction in Caulobacter crescentus. Genetics 87, 391-399.

Francis, M. M., Cella, R. \& Vining, L. C. (1975). Genetic recombination in a chloramphenicolproducing strain of Streptomyces spp 3022a. Canadian Journal of Microbiology 21, 1151-1159.

Hartman, P. E., Loper, J. C. \& Šerman, D. (1960). Fine structure mapping by complete transduction between histidine-requiring Salmonella mutants. Journal of General Microbiology 22, 323-353.

Hemphill, H. E. \& Whiteley, H. R. (1975). Bacteriophages of Bacillus subtilis. Bacteriological Reviews 39, 257-315.
Hopwood, D. A. (1967). Genetic analysis and genome structure in Streptomyces coelicolor. Bacteriological Reviews 31, 373-403.

Hopwood, D. A., Chater, K. F., Dowding, J. E. \& Vivian, A. (1973). Advances in Streptomyces coelicolor genetics. Bacteriological Reviews 37, 371-405.

Jones, L. A. \& Bradley, S. G. (1965). The life-cycle of an actinophage for Streptomyces venezuelae. Journal of General Microbiology 40, 191-198.

Levinthal, M. (1974). Bacterial genetics excluding E. coli. Annual Review of Microbiology 28, 219230.

Lomovskaya, N. D., Voeykova, T. A. \& MkrtuMIAN, N. M. (1977). Construction and properties of hybrids obtained in interspecific crosses between Streptomyces coelicolor A3(2) and Streptomyces griseus Kr.15. Journal of General Microbiology 98, 187-198.

Michelson, A. M. \& Vining, L. C. (1978). Loss of chloramphenicol production in strains of Streptomyces spp 3022a treated with acriflavine and ethidium bromide. Canadian Journal of Microbiology 24, 662-669.

Novikova, N. L., Lomovskaya, N. D. \& KapitoNOVA, O. N. (1973). Adsorption and development of $\phi \mathrm{C} 31$ actinophage in germinating spores of Streptomyces coelicolor A3(2). Microbiology 42, 454 458. (English translation of Mikrobiologiya 42, 513-518).

WELSCH, M. (1969). Biology of actinophages. Proceedings of the International Symposium on the Genetics and Breeding of Streptomyces, Dubrovnik, 1968, pp. 43-62. Edited by G. Sermonti \& M. Alačević. Zagreb: Yugoslav Academy of Science \& Art.

ZINDER, N. D. \& LeDerberG, J. (1952). Genetic exchange in Salmonella. Journal of Bacteriology 64, 679-699. 